$\begin{array}{ll}\text { Volume } & : 06 \\ \text { Nomor } & : 02 \\ \text { Bulan } & : \text { Mei } \\ \text { Tahun } & : 2020 \\ \text { http } & : \text { //ejurnal.pps.ung.ac.id/index.php/AKSARA/index }\end{array}$

\title{
Penggunaan Zoom Sebagai Pembelajaran Berbasis Online Dalam Mata Kuliah Sosiologi dan Antropologi Pada Mahasiswa PPKN di STKIP Kusumanegara Jakarta
}

\author{
Ismail Akbar Brahma \\ Prodi PPKN STKIP Kusumanegara Jakarta \\ ismail_akbar@stkipkusumanegara.ac.id
}

\begin{abstract}
Received: 23 Februari 2020; Revised: 27 April 2020; Accepted: 28 April 2020
DOI: http://dx.doi.org/10.37905/aksara.6.2.97-102.2020
\end{abstract}

\begin{abstract}
Abstrak
Pembelajaran online jarak jauh merupakan salah satu solusi yang dibutuhkan oleh tenaga pendidik dan mahasiswa di masa pandemi covid 19 yang terjadi pada februari 2020. Tujuan dari penelitian ini adalah untuk menggambarkan kondisi yang terjadi pada proses pembelajaran jarak jauh dengan menggunakan zoomsebagai alaternatif pemecahan masalah kegiatan pembelajaran pada mata kuliah sosiologi dan antropologi. Metode penelitian ini adalah deskriptif kualitatif dengan teknik pengumpulan data observasi, wawancara dan dokumentasi. Mandy Archibald, dkk hasil penelitiannya dengan menggunakan zoom mempermudah dalam mengumpulkan data kualitatif karena lebih efektif biaya dan kemanan terjaga.
\end{abstract}

Kata kunci: Zoom, Pembelajaran, Online

\begin{abstract}
Online learning is one of solution in long distance when the lecturers and college student didn'tinteraction in the class as long pandemic covid 19 from february 2020. The purpose of this research is to describe the situation on learning process using zoom application as an altermative in sociology and antropology course. Method the reseacrh is qualitative descriptive as collect data using observation, interview and documentation. Mandy Archibald, on his reseacrh used zoom to easy to collect qualitative data beacuse of more effective costand security.
\end{abstract}

Key Words: Zoom, Learning, Online

\section{PENDAHULUAN}

Pada masa work from home saat ini dengan adanya pandemi covid 19 yang melanda belahan dunia termasuk di Indonesia menjadikan banyaknya pekerjaan yang dilakukan oleh manusia dengan menggunakan ragam aplikasi yang menunjang pekerjaannya. Menurut Kevin dalam Kompas.com menyatakan bahwa zoom sebagai video conferencing ini banyak digunakan berbagai kalangan seperti pembelajaran jarak jauh yang dilakukan dosen dengan mahasiswa karena kualitas video dan audio 


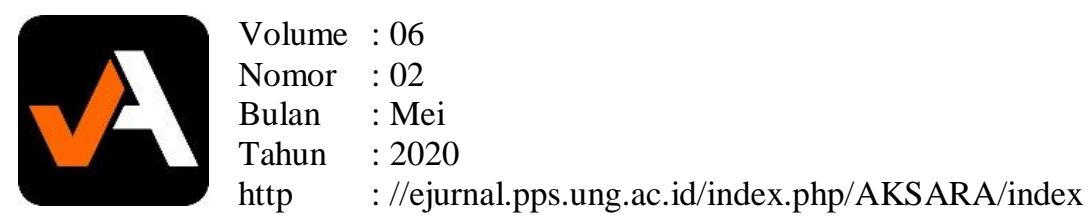

dapat tetap terjaga meskipun koneksi internet tidak stabil. Anak-anak generasi Z dimasa ini merupakan generasi yang terlahir pada zaman yang semakin canggih sehingga gaya dan media pembalajaran yang digunakan sangat generasi global dan visual. Dari hasil penelitiannya bahwa media pembelajaran menggunakan video sangat membantu dalam proses pembelajaran baik formal maupun non formal (Denissa, $2016: 85$ ).

Berangkat dari pandemi covid 19 di awal tahun Februari 2020, peneliti tertarik untuk melakukan penelitian tentang zoom yang digunakan sebagai alternatif dari pertemuan tatap muka yang diganti dengan video conferencing yang dapat diakses oleh mahasiswa dan dosen untuk tetap menjaga kualitas sehingga proses pembelajaran tetap berjalan meskipun di tengah wabah yang melanda negeri ini. Beragam aplikasi atau media pembelajaran bertebaran di tengah pandemi covid 19, namun peneliti lebih tertarik dengan menggunakan zoom karena lebih terjaga keamanannya dan efektif dalam melakukan diskusi atau pembahasan materi dengan komunikasi yang didukung dengan fitur-fitur yang terdapat di zoom seperti pesan grup sehingga jika ada kendala secara audio dapat dibantu dengan fiturchat yang tersedia.

\section{METODE}

Metode penelitian ini adalah menggunakan penelitian deskriptif kualitatif yaitu menggambarkan peristiwa yang terjadi pada saat melakukan pembelajaran secara online. Sampel yang digunakan adalah 25 mahasiswa program studi PPKN semester 4. Adapun langkah-langkah yang dilakukan dengan teknik pengumpulan data yaitu 1) melakukan observasi kepada mahasiswa untuk melihat interaksi dan minat serta respon pada saat pembelajaran online berlangsung , 2) wawancara kepada mahasiswa sebagai objek penelitian dan melakukan wawancara kepada Dosen sejawat sebagai tambahan untuk mendapatkan informasi sebagai informan yang mendukung terkait objek penelitian dan 3) melakukan dokumentasi terkait data-data yang relevan dengan hasil penelitian. Teknik analisis data dalam penelitian ini adalah reduksi data, penyajian data, dan kesimpulan.

\section{HASIL DAN PEMBAHASAN}

Hasil

Hasil penelitian ini yaitu penggunaan zoom dilakukan pada mahasiswa prodi PPKN untuk mata kuliah Sosiologi dan Antropologi semester 4 dari bulan MaretApril 2020. Penggunaan zoom menjadi alternatif pembelajaran jarak jauh bagi dosen dan mahasiswa di lingkungan STKIP Kusumamegara. Adapun langkah-langkah penggunaan zoom sebagai berikut:

1. Dosen mempersilahkan mahasiswa untuk mengunduh https:// zoom.us/support/download. Zoom dapat digunakan melalui handphone atau laptop.

98 AKSARA Jurnal Ilmu Pendidikan Nonformal 


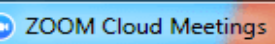

Gambar 1 Tampilan Awal Zoom

2. Pilih bergabung dengan rapat atau JoinMeeting

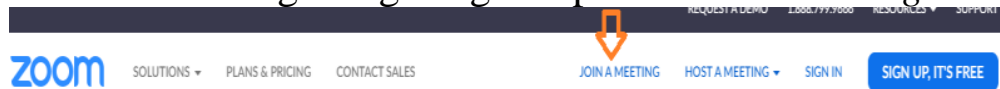

Join a Meeting

Meeting ID or Personal Link Name

Gambar 2. Mahasiswa memasukkan ID dari dosen yang telah memberikanpassworddan ID dalammeetingatau mengundang melalui email.

3. Semua mahasiswa dan dosen dapat berkomunikasi untuk berdiskusi dan memberikan serta chatting bersama melalui video conference 

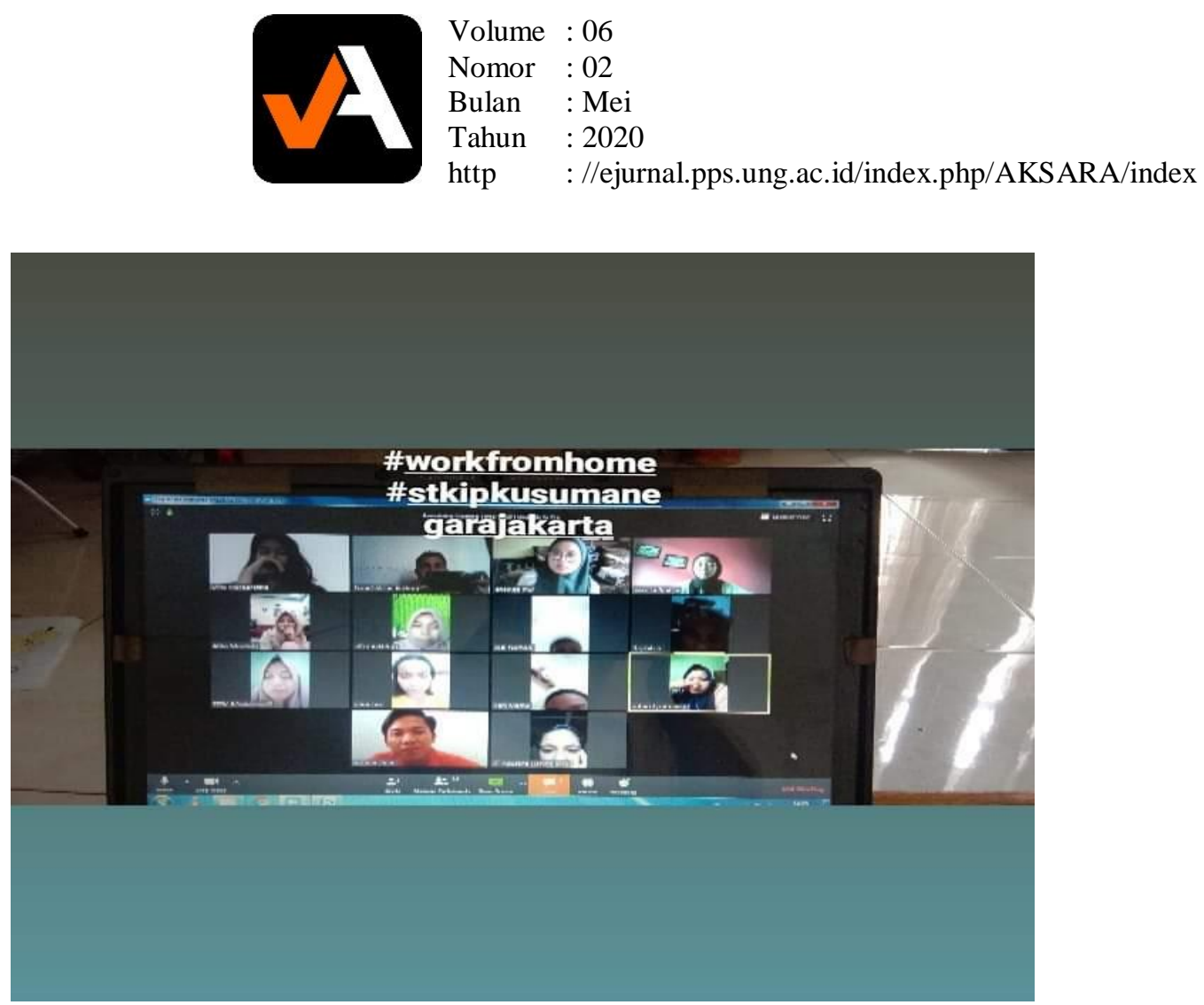

Gambar 3. Join meeting mata kuliah sosiologi dan antropologi

Melalui zoom dijadikan pembelajaran onlinejarak jauh menjadikan pembelajaran lebih efektif. Hal ini karena zoom menyediakan video konfrensi yang dapat dijangkau oleh seluruh partisipan atau mahasiswa dan dosen. Selain itu, rekaman video pun terjaga keamanannya dan memiliki fiturchatting sehingga jika ada yang mendapatkan pendengaran dengan baik pada saat video konferensi maka dapat berbicara melalui chatting. Dalam zoom dapat pula dilakukan penjadwalan meeting berikutnya yang akan dilakukan. Dengan memanfaatkan pembelajaran online ini, tentunya menjadi solusi yang sangat inovatif di tengah pandemi covid 19 yang menuntut masyarakat untuk work form home termasuk kegiatan pembelajaran di perkuliahan melalui online.

Mahasiswa dalam menerima materi sebelumnya diberikan email oleh dosen untuk dipelajari terlebih dahulu lalu didiskusikan pada video konfrensi tersebut. Mahasiswa sangat tertarik mempelajari sosiologi dan antropologi secara online karena mahasiswa dapat dengan santai menerima pembelajaran dirumah tanpa harus tatap muka dengan tetap fokus berdiskusi melalui zoom dengan dosen dan teman sejawat lainnya. Adapun kekurangan dari zoom yaitu bertahan dengan waktu 45 menit di sesi pertama, untuk berikutnya harus sign in kembali untuk masuk joinmeeting di sesi berikutnya. Kekurangan lain yaitu, dengan menghabiskan waktu 15-20 menit di awal untuk siap semua partisipan menghadiri video konferensi. Dengan berbagai kendala mahasiswa seperti, tidak jelasnya audio, visual, dan koneksi jaringan di awal menghambat pembelajaran di awal menggunakan zoom. Tetapi setelah semuanya hadir dan siap maka zoom pun dapat berjalan efektif. Mahasiswa dan dosen sangat bergantung pada jaringan internet dalam penggunaan zoom yang efektif. Jika 


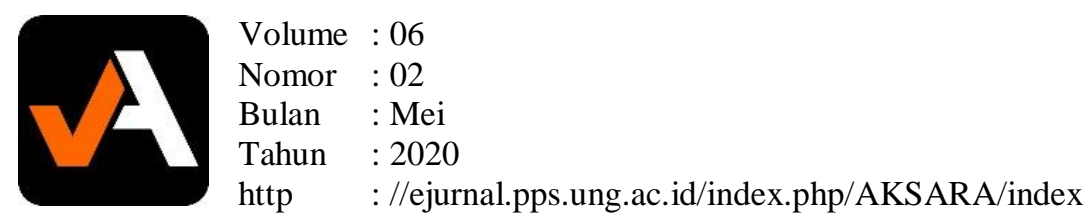

jaringan internet terputus maka akan menghambat kegiatan pembelajaran melalui joinmeeting pada fiturzoom.

\section{PEMBAHASAN}

Dari hasil penelitian di atas didukung pula seperti halnya penelitian yang pernah dilakukan dengan Penggunaan media pembelajaran yang dilakukan dari hasil penelitian Yohana Chandra dan Munoto bahwa Zooming user interface di SMKN 3 Surabaya pada mata pelajaran Perekayasaan Sistem Antena di kelas Xi TAV, dilakukan dengan efektif dan praktis untuk mengembangkan bahan ajar, RPP dan indikator yang dicapai dalam pembelajaran. Selain itu, (Firda Ayu, dkk, 2016: 14)menyatakan dari hasil penelitiannya bahwa mobile learning merupakan pengembangan dari e-learning yang dapat digunakan kapan dan dimana saja tanpa perlu tatap muka secara langsung. Melalui pembelajaran jarak jauh ini dapat memaksimalkan pembelajaran yang diterima oleh mahasiswa selain di dalam kelas , namun dapat dilakukan diluar kelas melalui aplikasi mobile learning yang mampu di akses oleh mahasiswa dan dosen. Dosen dan mahasiswa dapat melakukan diskusi dan tanya jawab melalui pembelajaran secara online. Zoom merupakan layanan konferensi video berbasis cloud termasuk pertemuan online, pengiriman pesan grup dan perekaman sesi yang aman .

\section{SIMPULAN}

Berdasarkan hasil penelitian di atas maka dapat disimpulkan bahwa zoom menjadi alternatif media pembelajaran onlineditengah pandemi covid 19. Mahasiswa dan dosen tetap menjalankan kegiatan pembelajaran secara jarak jauh. Melalui zoom, dosen dan mahasiswa dapat melakukan video konferensi yang dijadikan sarana berkomunikasi dalam pembelajaran secara online. Melauizoom, lebih terjaga kemanan rekaman yang dilakukan pada saat meeting berlangsung. Mata kuliah sosiologi dan antropologi menjadi lebih interaktif dan diminati oleh mahasiswa karena media pembelajaran online yang digunakan sangat inovatif dan efektif sesuai dengan perkembangan zaman. Keberlangsungan video konferensi pada zoom ini bergantung pada jaringan internet sehingga dosen dan mahasiswa harus menggunakan akses internet agar dapat menggunakan aplikasi zoom. 


\section{DAFTAR PUSTAKA}

Denissa Alfiani, dkk. 2016. Pembelajaran Berbasis Video Untuk Anak Generasi Z.Prosiding Inovasi Pendidikan di Era Big Data dan Aspek Psikologinya .ISSN: 2548-5407. PascaSarjana Universitas Negeri Malang. hal 85-92

Firda Ayu, dkk. 2016. Pembelajaran Berbasis Online SocialNetworking (OSN) dalam Meningkatkan Kemampuan Menulis ArgumentativeEssay Mahasiswa. Prosiding Inovasi Pendidikan di Era Big Data dan Aspek Psikologinya .ISSN: 2548-5407. PascaSarjana Universitas Negeri Malang. Hal. 145-150.

Kevin. 2020. Alasan Zoom Banyak Dipakai untuk Rapat Hingga Kuliah dari Rumah. 24 Maret 08:02. Tekno.compas.com

Mandy, Archibald, Rachel dan Mavourneen. 2019. Menggunakan Zoom Video Conferencing untuk Pengumpulkan Data Kualitatif: Persepsi dan Pengalaman Para Peneliti dan Peserta. Jurnal Internasional Metode Kualitatif. 11 September . https://doi.org/10.1177\%2F1609406919874596

Yohana chandra dan Munoto. 2018. Pengembangan Perangkat Pembelajaran Menggunakan Model Pembelajaran Langsung Dengan Media ZoomingUserInterface Pada Mata Pelajaran Perekayasaan Sistem Antena Kelas XI SMKN3 Surabaya. Jurnal Pendidikan Teknik ElektroVol.7 No. 1.Hal 87-93. 